\title{
生理機能検査の利用件数
}

病院の建築計画に関する研究——

$\begin{array}{ccccc}\text { 正会員 } & \text { 伊 } & \text { 藤 } & & \text { 誠* } \\ " & \text { 幡 } & \text { 野 } & \text { 公 } & \text { 人** } \\ " & \text { 野 } & \text { 田 } & \text { 浩 } & \text { 史** } \\ \text { " } & \text { 杉 } & \text { 谷 } & \text { 俊 } & \text { 夫** }\end{array}$

\section{§1. 研究の目的と方法}

(1) 目的：病院に抢ける検查のうち，いわゆる生理 学的な機能検查は, それが中央化された場合, 必然的に 患者の移動を伴うことになる。その点で血液や尿など検 体をしらべる臨床病理学的な検查とは，同じ検査でも根 本的に性格を異にする。患者の動きを必要とする生理機 能検査では，その動きの性格，つまり使われ方の量的な 内容を把握することが建築計画上きわめて重要な課題と なる。このよらな観点から，その状沉の一端をかって本 学会において報告した（筧和夫・伊藤誠「検查施設につ いて」学会論文報告集 54 号 1956 年 9 月)。しかし，そ の後 10 年以上を経過した今日，この方面の発展は殊の ほか目ざましく，特に心電図のごときは今やごく日常的 な検査となり，その件数も格段に増加した。本稿は，生 理機能検查のうち，総合病院に拄いて比較的一般化して 、る心電図・脳波・筋電図・基礎代謝・呼吸機能の 5 項 目をとりあげて，その利用の現況を調查したものの結果 である。病院の設計において，生理機能検查部門にどの 程度の規模を与え，またそれを院内のどこに配置すべき かについての手がかりを得べく，前論文を追跡しつつさ らに掘りさげた分析をおこなった。

（2） 方法：調查対象としては東京都内の公的な総合 表一1 調查対象病院の概要

\begin{tabular}{|c|c|c|c|c|c|c|c|c|c|c|}
\hline 病 院 名 ${ }^{1}$ & 略称 & $\stackrel{ッ}{*}$ 数 & $\begin{array}{l}1 \text { 日平 } \\
\text { 均外来 } \\
\text { 患者数 }\end{array}$ & $\begin{array}{r}2) \\
\text { 外来 } \\
\text { 率 }\end{array}$ & $\frac{t}{\text { 心電 }}$ & $\frac{1}{\text { 㨫波 }}$ & 械 & $\frac{\text { 台 偻 }}{\text { 基礎 }}$ & \begin{tabular}{|l} 
女两吸 \\
機能 \\
\end{tabular} & 技赬 \\
\hline 国立東京第一病院* & 東一 & 588 & 976 & 1.7 & 3 & 2 & 1 & 1 & 1 & 2 \\
\hline 国立東京第二病院* & 宋二 & 850 & 988 & 1.2 & 4 & 2 & 1 & 2 & 2 & 4 \\
\hline 都立広尾 病 院* & 広尾 & 366 & 674 & 1.8 & 1 & 0 & 0 & 0 & 1 & 2 \\
\hline 都立豊島 病 院 & 豊島 & $224^{3)}$ & 587 & 2.6 & 2 & 1 & 1 & 0 & 0 & 2 \\
\hline 社含保険中央病院 & 社保 & 300 & 562 & 1.9 & 3 & 1 & 1 & 1 & 1 & 3 \\
\hline 武蔵野赤十字病院 & 武赤 & 540 & 1030 & 1.9 & 1 & 1 & 1 & 1 & 0 & 3 \\
\hline 聖路加国際病院 & 聖路加 & 369 & 957 & 2.6 & 5 & 1 & 3 & 1 & 1 & 6 \\
\hline 虎 の 門 病 院* & 虎の門 & 467 & 1332 & 2.9 & 5 & 2 & 2 & 1. & 3 & 17 \\
\hline 関東中央病院 & 関中 & 501 & 755 & 1.5 & 3 & 1 & 0 & 1 & 1 & 3 \\
\hline
\end{tabular}

1）“印は’66 年 10 月現在，他は'67 年 10 月現在。

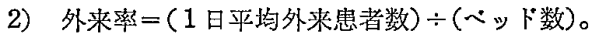

3) 豊島病院のベッド数については伝染病 265 床を除く。

*千葉大学助教授 **同大学院生

（昭和 43 年 7 月 8 日 本稿受理 - 討論期限 昭和 44 年 3 月末日)
病院のうちから 9 病院 (表一1)をえらび, 各病院にお ける検查伝票・検査原簿等から検査種目別の件数をしら べた。なお，調查は 1966 年から 67 年にかけておこな った。

§2. 検查件数の経年変化亡月変動

(1) 経年変化：前述の生理検査 5 項目について最近 数年間の件数を一覧にしたのが表一2である。

表一2 生理検査総件数の経年変化

\begin{tabular}{|c|c|c|c|c|c|c|c|}
\hline 房 院 & 年 & 1961 & 1962 & 1963 & 1964 & 1965 & 1966 \\
\hline 東 & - & $\begin{array}{l}5,845 \\
(100)\end{array}$ & $\begin{array}{l}6,281 \\
(108)\end{array}$ & $\begin{array}{l}7,327 \\
\text { (125) }\end{array}$ & $\begin{array}{l}7,579 \\
(130)\end{array}$ & $\begin{array}{l}8,149 \\
\text { (139) }\end{array}$ & $\begin{array}{l}8,059 \\
(138)\end{array}$ \\
\hline 東 & $=$ & $\begin{array}{l}\mathbf{5 , 4 8 9} \\
(100)\end{array}$ & $\begin{array}{l}6,489 \\
(118)\end{array}$ & $\begin{array}{l}7,349 \\
(134)\end{array}$ & $\begin{array}{l}7,619 \\
(139)\end{array}$ & $\begin{array}{l}8,230 \\
(150)\end{array}$ & $\begin{array}{l}8,679 \\
(158)\end{array}$ \\
\hline 広 & 尾 & $\begin{array}{l}2,146 \\
(100)\end{array}$ & $\begin{array}{r}2,105 \\
(98)\end{array}$ & $\begin{array}{l}2,416 \\
\text { (113) }\end{array}$ & $\begin{array}{l}2,187 \\
(102)\end{array}$ & $\begin{array}{l}2,320 \\
(108)\end{array}$ & $\begin{array}{l}2,254 \\
(105)\end{array}$ \\
\hline 社 & 保 & $\cdots$ & $\begin{array}{l}1,640 \\
(100)\end{array}$ & $\begin{array}{l}2,238 \\
(136)\end{array}$ & $\begin{array}{l}2,344 \\
\text { (143) }\end{array}$ & $\begin{array}{l}3,787 \\
(231)\end{array}$ & $\begin{array}{l}4,050 \\
(247)\end{array}$ \\
\hline 武 & 赤 & $\cdots$ & $\cdots$ & $\begin{array}{l}2,884 \\
(100)\end{array}$ & $\begin{array}{l}3,348 \\
\text { (116) }\end{array}$ & $\begin{array}{l}3,860 \\
(134)\end{array}$ & $\begin{array}{l}4,276 \\
(148)\end{array}$ \\
\hline 聖 路 & 加 & $\cdots$ & $\cdots$ & $\begin{array}{l}8,887 \\
(100)\end{array}$ & $\begin{array}{l}9,209 \\
(104)\end{array}$ & $\begin{array}{l}9,320 \\
(105)\end{array}$ & $\begin{array}{r}10,021 \\
\text { (113) }\end{array}$ \\
\hline 虎 の & 門 & $\cdots$ & $\cdots$ & $\begin{array}{r}13,169 \\
(100)\end{array}$ & $\begin{array}{r}14,069 \\
(107)\end{array}$ & $\begin{array}{r}15,969 \\
(121)\end{array}$ & $\begin{array}{r}21,169 \\
(161)\end{array}$ \\
\hline 関 & 中 & $\cdots$ & ... & $\begin{array}{l}3,784 \\
(100)\end{array}$ & $\begin{array}{l}5,271 \\
(139)\end{array}$ & $\begin{array}{l}6,157 \\
(163)\end{array}$ & $\begin{array}{l}7,374 \\
(195)\end{array}$ \\
\hline
\end{tabular}

1）各欄上段は実数，下段（）内は調査初年度を 100 とした指数。

2）〈武赤〉の場合，筋電図は整形外科で使用しているが，その記録が 得られなかったのでここには算入していない。

3）<宏尾>の数值は1月から 12 月末での合計。他は各年度の值。

4）以下，各表とも表中に使用する記号は次のとおりである。

一計数のない場合， …計数不明の場合，一統計項目のあり得な い場合。

件数の絶対值に恔病によってだいぶ大きな差がある が，それぞれを経年的にみるといずれも漸増もしくは急 増している。はなはだしい例では，<社保〉<関中>の ように 3 年間でほぼ倍増しているものさえある。因みに これらの病院の患者総数をみると（表一3），以ずれもほ としど固定した值を示している。すなわち，検査をらけ る割合が急激に増しつつあることが理解できよう。

検査をうける割合の増加傾向索指数的に算出してみた のが表一4である。

（2）月変動：たとえば，外来患者数には年間を通し て比較的大きな季節変動がある。このことは既に広く知 られているが，患者総数に変動があれば検查件数にも影 
表一3 患者延数の経年変化

\begin{tabular}{|c|c|c|c|c|c|c|}
\hline \multicolumn{2}{|c|}{ 年 度 } & 1962 & 1963 & 1964 & 1965 & 1966 \\
\hline \multirow[b]{2}{*}{ 入 } & 社 保 & $\begin{array}{c}101,948 \\
(100)\end{array}$ & $\begin{array}{r}101,086 \\
(99)\end{array}$ & $\begin{array}{r}94,015 \\
(92)\end{array}$ & $\begin{array}{r}97,567 \\
(96)\end{array}$ & $\begin{array}{r}96,622 \\
(95)\end{array}$ \\
\hline & 武 赤 & $\begin{array}{r}155,426 \\
(100)\end{array}$ & $\begin{array}{r}164,003 \\
\text { (106) }\end{array}$ & $\begin{array}{r}162,567 \\
(105)\end{array}$ & $\begin{array}{r}161,291 \\
(104)\end{array}$ & $\begin{array}{r}162,483 \\
\text { (105) }\end{array}$ \\
\hline \multirow{2}{*}{ 院 } & 聖路加 & $\cdots$ & $\begin{array}{r}118,072 \\
(100)\end{array}$ & $\begin{array}{r}113,782 \\
(96)\end{array}$ & $\begin{array}{r}112,673 \\
(95)\end{array}$ & $\begin{array}{r}108,808 \\
(92)\end{array}$ \\
\hline & 関 中 & $\cdots$ & $\begin{array}{r}139,787 \\
(100)\end{array}$ & $\begin{array}{r}132,697 \\
(95)\end{array}$ & $\begin{array}{r}138,683 \\
(99)\end{array}$ & $\begin{array}{r}132,020 \\
(94)\end{array}$ \\
\hline \multirow[b]{2}{*}{ 外 } & 社 保 & $\begin{array}{c}164,738 \\
(100)\end{array}$ & $\begin{array}{c}170,473 \\
(103)\end{array}$ & $\begin{array}{r}172,104 \\
(104)\end{array}$ & $\begin{array}{c}175,269 \\
\text { (106) }\end{array}$ & $\begin{array}{r}168,643 \\
(102)\end{array}$ \\
\hline & 武 赤 & $\begin{array}{r}299,779 \\
(100)\end{array}$ & $\begin{array}{l}300,705 \\
\quad(100)\end{array}$ & $\begin{array}{c}298,742 \\
(100)\end{array}$ & $\begin{array}{c}300,744 \\
(100)\end{array}$ & $\begin{array}{l}309,082 \\
\text { (103) }\end{array}$ \\
\hline \multirow{2}{*}{ 来 } & 聖路加 & $\ldots$ & $\begin{array}{r}287,776 \\
(100)\end{array}$ & $\begin{array}{r}291,431 \\
\text { (101) }\end{array}$ & $\begin{array}{r}292,831 \\
(102)\end{array}$ & $\begin{array}{r}287,097 \\
(100)\end{array}$ \\
\hline & 関 中 & $\cdots$ & $\begin{array}{c}188,864 \\
(100)\end{array}$ & $\begin{array}{c}200,535 \\
(106)\end{array}$ & $\begin{array}{r}220,724 \\
\quad(117)\end{array}$ & $\begin{array}{r}226,830 \\
(120)\end{array}$ \\
\hline
\end{tabular}

各㯗上段は実数，下段（）内は調查初年度を100 とした指数。 表一4 生理検查総件数の患者延数に対する割合*

\begin{tabular}{|c|c|c|c|c|c|c|}
\hline 病 院 & 年 & 1962 & 1963 & 1964 & 1965 & 1966 \\
\hline 社 & 保 & 0.61 & 0.82 & 0.88 & 1.39 & 1.53 \\
\hline 武 & 赤 & .. & 0.62 & 0.73 & 0.84 & 0.91 \\
\hline 聖 路 & 加 & $\cdots$ & 2.43 & 2.50 & 2.54 & 2.73 \\
\hline 関 & 中 & ... & 1.15 & 1.58 & 1.71 & 2.05 \\
\hline
\end{tabular}

* (年間生理検查総件数 $) \div($ 年間入院患者延数 + 年間外来患者延数 $) \times 100$ として求めた。

響があらわれるであろうことは当然である。

入院・外来の双方に関して月ごとの患者数と検查件数 と定<社保 $><$ 武赤 $><$ 関中 $>の 3$ 病院についてみたの

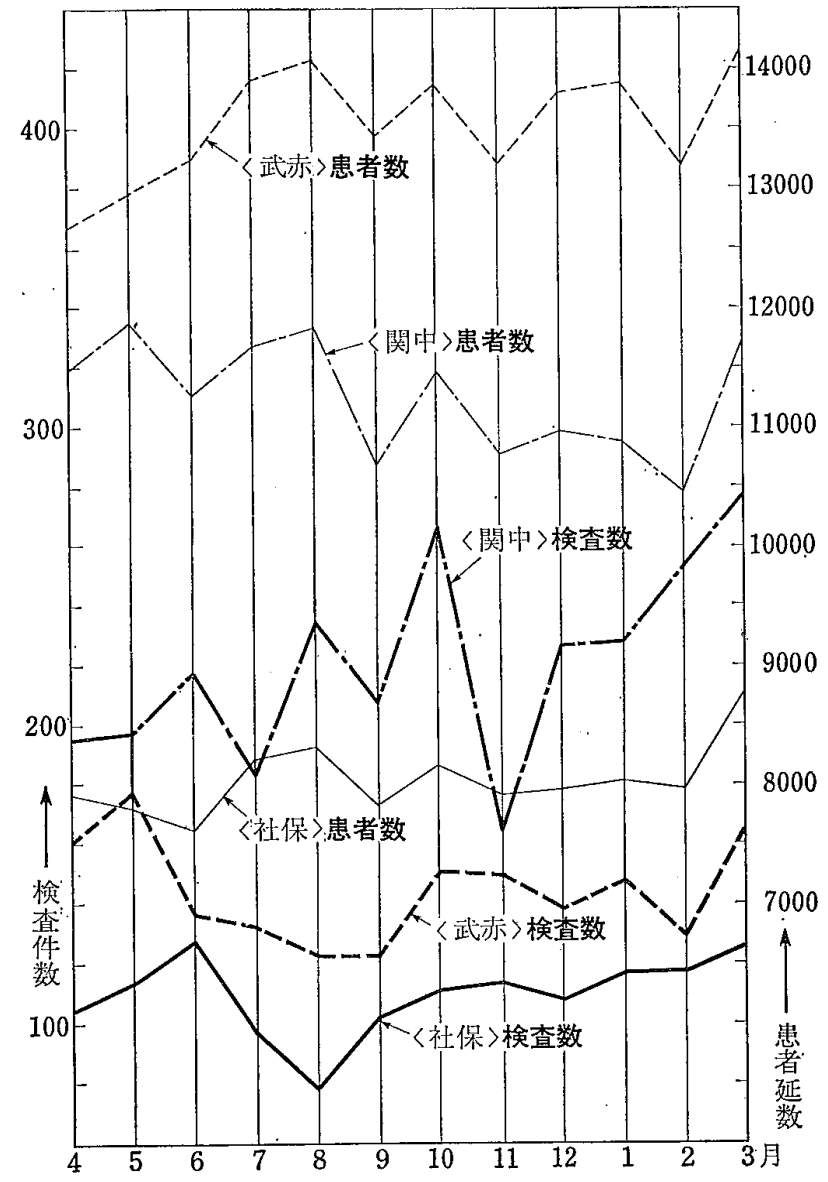

図一1 患者数と検查件数の月变動（入院）1966 年度

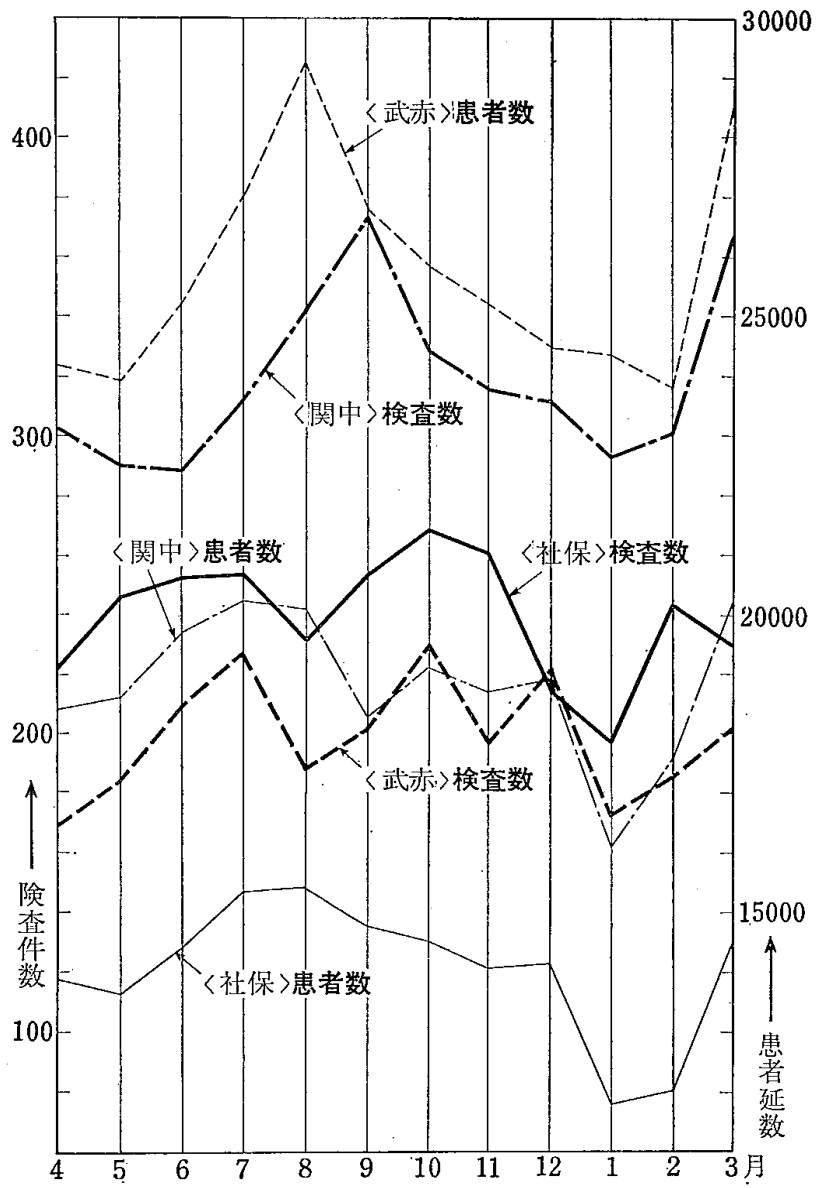

図一2 患者数と検查件数の月变動 (外来) 1966 年度 が図一1，2 である。いずれも，検查件数は拉扔む敉患 者数に比例して変動していることがわかる。つまり，入 院・外来とも患者のうち生理検査をうけるものの割合 は，病院ごとにほぼ一定しているといえる。この割合を 算出してみると表一5 のよらになる。

表一5 患者のうち生理検查をらけるものの 月別割合（1966 年度）

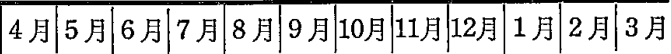

1) 社 保 $|1.31| 1.45|1.67| 1.17|0.93| 1.30|1.34| 1.43|1.35| 1.45|1.47| 1.43$

入 武赤 $1.271 .371 .030 .950 .87|0.91| 1.081 .131 .001 .06 \mid 0.971 .16$

院 関 中 $1.68|1.66| 1.94|1.56| 1.99|1.94| 2.33|1.51| 2.06|2.09| 2.42 \mid 2.35$

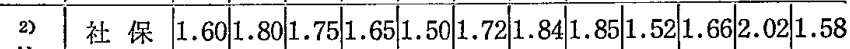

外武赤 $0.70|0.760 .83| 0.84|0.64| 0.74|0.88| 0.78|0.90| 0.71|0.78| 0.70$

来関中 $1.63|1.55| 1.46|1.53| 1.69|2.04| 1.72|1.68| 1.64|1.81| 1.71 \mid 1.81$

1）入院については（入院生理検查延数）（入院患者延数） $\times 100$ 。

2) 外来については（外来生理検査延数） $\div$ (外来患者延数) $\times 100$ 。

この結果からみて，やや危険はあるが，以下の検査種 目別考察は1か月だけの件数についておこならこととす る。

\section{§3. 種目別検查件数}

生理検査の件数を種目別に比較してみると表一6 のよ らになる。病院によっては，ある種の検查を全然おこな っていないてころもあるが，それはともかくとして，全 体的には，心電図が他上りもか忊はなれて多い（70８5 \%)。次いで脳波の普及が注目される。西的，基礎代 謝がある程度の割合を占めているだけで，筋電図・呼吸 機能にいたっては格段に少なくなっている。 
表一6 検査種目別件数とその比率

\begin{tabular}{|c|c|c|c|c|c|c|c|}
\hline & & 心電図 & 脳 波 & 筋電図 & 基礎代謝 & 呼吸機能 & 訫 \\
\hline 東 & 一* & $\begin{array}{l}510 \\
(80)\end{array}$ & $\begin{array}{c}77 \\
\text { (12) }\end{array}$ & $\begin{array}{c}2 \\
(0)\end{array}$ & $\begin{array}{l}38 \\
(6)\end{array}$ & $\begin{array}{l}15 \\
(2)\end{array}$ & $\begin{array}{c}642 \\
(100)\end{array}$ \\
\hline 東 & $二^{*}$ & $\begin{array}{l}553 \\
(86)\end{array}$ & $\begin{array}{l}20 \\
(3)\end{array}$ & $\begin{array}{c}4 \\
\text { (1) }\end{array}$ & $\begin{array}{c}65 \\
(10)\end{array}$ & $\begin{array}{c}4 \\
\text { (1) }\end{array}$ & $\begin{array}{c}646 \\
(100)\end{array}$ \\
\hline 広 & 尾* & $\begin{array}{l}174 \\
(\cdots)\end{array}$ & $\cdots$ & • & . & $\begin{array}{c}12 \\
(\cdots)\end{array}$ & $\begin{array}{c}186 \\
(100)\end{array}$ \\
\hline 豊 & 島 & $\begin{array}{l}117 \\
(67)\end{array}$ & $\begin{array}{c}51 \\
(30)\end{array}$ & $\begin{array}{c}5 \\
(3)\end{array}$ & • & $\cdot$ & $\begin{array}{c}173 \\
(100)\end{array}$ \\
\hline 社 & 保 & $\begin{array}{l}248 \\
(71)\end{array}$ & $\begin{array}{l}74 \\
(21)\end{array}$ & $\begin{array}{l}14 \\
(4)\end{array}$ & $\begin{array}{l}13 \\
(4)\end{array}$ & - & $\begin{array}{c}349 \\
(100)\end{array}$ \\
\hline 武 & 赤 & $\begin{array}{c}368 \\
(\cdots)\end{array}$ & $\begin{array}{c}53 \\
(\cdots)\end{array}$ & $\cdots$ & $\begin{array}{c}26 \\
(\cdots)\end{array}$ & • & $\begin{array}{c}447 \\
(100)\end{array}$ \\
\hline 聖＼cjkstart路 & 加 & $\begin{array}{l}607 \\
(76)\end{array}$ & $\begin{array}{l}159 \\
(20)\end{array}$ & $\begin{array}{c}2 \\
(0)\end{array}$ & $\begin{array}{l}23 \\
\text { (3) }\end{array}$ & $\begin{array}{c}9 \\
(1)\end{array}$ & $\begin{array}{r}800 \\
(100)\end{array}$ \\
\hline 虎 の & 門* & $\begin{array}{l}731 \\
(74)\end{array}$ & $\begin{array}{l}121 \\
\text { (12) }\end{array}$ & $\begin{array}{l}15 \\
\text { (1) }\end{array}$ & $\begin{array}{l}39 \\
(4)\end{array}$ & $\begin{array}{c}80 \\
(8)\end{array}$ & $\begin{array}{r}986 \\
(100)\end{array}$ \\
\hline 関 & 中 & $\begin{array}{l}410 \\
(81)\end{array}$ & $\begin{array}{l}65 \\
(13)\end{array}$ & - & $\begin{array}{l}30 \\
(6)\end{array}$ & $\begin{array}{c}1 \\
(0)\end{array}$ & $\begin{array}{c}506 \\
(100)\end{array}$ \\
\hline
\end{tabular}

*印の病院については 1966 年 10 月（1か月間）の值。

その他は 1967 年 10 月 ( 1 名月間) の值。

以下，表一7 からら表一18 まで同様。

\section{§4. 心電図}

表一7 大院 - 外来別心電図件数と元の比率

\begin{tabular}{|c|c|c|c|c|c|c|}
\hline & \multicolumn{2}{|l|}{ 入 } & \multicolumn{2}{|l|}{ 外 } & \multirow{2}{*}{ 計 } \\
\hline & & $\mathrm{N}$ & I & $\mathrm{N}$ & $\mathrm{O}$ & \\
\hline 東 & -* & $\begin{array}{l}218 \\
(43)\end{array}$ & 1.5 & $\begin{array}{l}290 \\
(57)\end{array}$ & 1.2 & $\begin{array}{c}508^{1)} \\
(100)\end{array}$ \\
\hline 東 & 二* & $\begin{array}{l}212 \\
(39)\end{array}$ & 1.0 & $\begin{array}{l}334 \\
(61)\end{array}$ & 1.4 & $\begin{array}{l}546^{2)} \\
(100)\end{array}$ \\
\hline 広 & 尾* & $\begin{array}{l}106 \\
(61)\end{array}$ & 1.2 & $\begin{array}{c}68 \\
(39)\end{array}$ & 0.4 & $\begin{array}{c}174 \\
(100)\end{array}$ \\
\hline 豊 & 島 & $\begin{array}{c}56 \\
(48)\end{array}$ & 1.0 & $\begin{array}{c}61 \\
(52)\end{array}$ & 0.4 & $\begin{array}{c}117 \\
(100)\end{array}$ \\
\hline 社 & 保 & $\begin{array}{c}76 \\
(31)\end{array}$ & 1.0 & $\begin{array}{l}172 \\
(69)\end{array}$ & 1.2 & $\begin{array}{c}248 \\
(100)\end{array}$ \\
\hline 武 & 赤 & $\begin{array}{l}188 \\
(51)\end{array}$ & 1.4 & $\begin{array}{l}179 \\
(49)\end{array}$ & 0.6 & $\begin{array}{c}3673) \\
(100)\end{array}$ \\
\hline 聖 & 路 加 & $\begin{array}{l}325 \\
(54)\end{array}$ & 3.5 & $\begin{array}{l}282 \\
(46)\end{array}$ & 1.2 & $\begin{array}{c}607 \\
(100)\end{array}$ \\
\hline 虎 & の 門* & $\begin{array}{l}304 \\
(42)\end{array}$ & 2.6 & $\begin{array}{l}427 \\
(58)\end{array}$ & 2.2 & $\begin{array}{c}731 \\
(100)\end{array}$ \\
\hline 関 & 中 & $\begin{array}{l}212 \\
(52)\end{array}$ & 1.7 & $\begin{array}{l}198 \\
(48)\end{array}$ & 1.1 & $\begin{array}{c}410 \\
(100)\end{array}$ \\
\hline
\end{tabular}

$\mathrm{N}: 1$ か月間に検查を受けた患者数とその比率。

I : 100 枺当り 1 日の入院検査件数。

$\mathrm{O}:$ 外来虫者延 100 人当门の外来柃査件数。

1) 外来・入院の区別不明のもの 2 を除く。

2) 同上 7 を除く。3) 同上 1 を除く。
（1）入院-外来別件数：心電図の件数を入院 - 外来 別にみたのが表-7 である。比率に関して，どちらかと 言えば外来の方がやや多めになっている。

（2）入院各科別件数：病棟からの利用を診療科別に 集計したのが表一8 である。内科からの利用が多いが， 外科からの利用も少なくはない。中にはく豊島〉のよう に外科の方が多、例さえある。手術との関連において心 電図検查を必要とするケースが多いためであろう。

表一8 入院各科別心電図件数とその比率

\begin{tabular}{|c|c|c|c|c|c|c|c|c|c|}
\hline & 内科 & 外科 & 脳外科 & $\begin{array}{l}\text { 整形 } \\
\text { 科 }\end{array}$ & 小児科 & 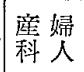 & $\begin{array}{l}\text { 泌 原 } \\
\text { 科 }\end{array}$ & その他 & 計 \\
\hline 豊 島 & $\begin{array}{c}22 \\
(39)\end{array}$ & $\begin{array}{c}27 \\
(48)\end{array}$ & - & - & $\begin{array}{c}4 \\
(7)\end{array}$ & $\begin{array}{c}3 \\
(6)\end{array}$ & - & - & $\begin{array}{c}56 \\
(100)\end{array}$ \\
\hline 社 保 & $\begin{array}{r}45 \\
(59)\end{array}$ & $\begin{array}{l}16 \\
(21)\end{array}$ & $\begin{array}{c}3 \\
(4)\end{array}$ & $\begin{array}{c}5 \\
(7)\end{array}$ & (1) & - & $\begin{array}{c}6 \\
(8)\end{array}$ & - & $\begin{array}{c}76 \\
(100)\end{array}$ \\
\hline 武 赤 & $\begin{array}{l}103 \\
(55)\end{array}$ & $\begin{array}{r}25 \\
(13)\end{array}$ & - & $\begin{array}{r}20 \\
\text { (11) }\end{array}$ & $\begin{array}{l}12 \\
(6)\end{array}$ & $\begin{array}{l}10 \\
(5)\end{array}$ & $\begin{array}{l}2 \\
(1)\end{array}$ & $\begin{array}{l}16 \\
(9)\end{array}$ & $\begin{array}{c}188 \\
(100)\end{array}$ \\
\hline 聖路加 & $\begin{array}{l}193 \\
\text { (59) }\end{array}$ & $\begin{array}{c}57 \\
(17)\end{array}$ & $\begin{array}{l}12 \\
(4)\end{array}$ & $\begin{array}{c}4 \\
(1)\end{array}$ & $\begin{array}{l}22 \\
(7)\end{array}$ & $\begin{array}{l}23 \\
(7)\end{array}$ & $\begin{array}{l}12 \\
(4)\end{array}$ & $\begin{array}{c}2 \\
(1)\end{array}$ & $\begin{array}{r}325 \\
(100)\end{array}$ \\
\hline 関 中 & $\begin{array}{l}182 \\
(86)\end{array}$ & $\begin{array}{l}17 \\
(8)\end{array}$ & . & $\begin{array}{c}3 \\
(1)\end{array}$ & $\begin{array}{l}1 \\
(0)\end{array}$ & $\begin{array}{c}7 \\
(3)\end{array}$ & - & $\begin{array}{l}2 \\
(1)\end{array}$ & $\begin{array}{c}212 \\
(100)\end{array}$ \\
\hline
\end{tabular}

ここで，参考のために各科別人院患者数を挙げておく (表一9)

（3）外来各科別件数：外来分らの利用学診療科別に みたのが 表一10 である。大半を内科，残り僅かを小児 科・産婦人科・その他によって占められている。<武赤> の耳鼻咽喉科のように高い比率を示す特例もあるが，こ の辺は医師の診療方針上の特殊性によるものと解してよ からら。

表一10 外来各科別心電図件数とその比率

\begin{tabular}{|c|c|c|c|c|c|c|c|c|c|c|}
\hline \multirow{2}{*}{\multicolumn{2}{|c|}{ 震 }} & \multirow[b]{2}{*}{ 一* } & \multirow{2}{*}{$\begin{array}{r}\text { 内 科 } \\
261 \\
(90)\end{array}$} & \multirow{2}{*}{ 外 科 } & \multirow{2}{*}{$\frac{\text { 整形 }}{\text { 科 }}$} & \multirow{2}{*}{\begin{tabular}{|l} 
小巟科 \\
$\begin{array}{r}5 \\
(2)\end{array}$
\end{tabular}} & \multicolumn{2}{|c|}{ 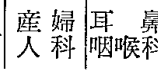 } & \multirow{2}{*}{\begin{tabular}{|c|} 
その他 \\
24 \\
$(8)$
\end{tabular}} & \multirow{2}{*}{ 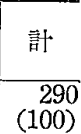 } \\
\hline & & & & & & & - & - & & \\
\hline 菓 & & 二* & $\begin{array}{r}291 \\
(87) \\
\end{array}$ & - & - & $\begin{array}{r}9 \\
(3)\end{array}$ & - & - & $\begin{array}{r}34 \\
(10)\end{array}$ & $\begin{array}{r}334 \\
(100) \\
\end{array}$ \\
\hline 広 & & 尾* & $\begin{array}{r}60 \\
(88) \\
\end{array}$ & - & - & (1) & - & - & ${ }^{7}{ }^{7}$ & $\begin{array}{r}68 \\
(100)\end{array}$ \\
\hline 㤟 & & 島 & $\begin{array}{r}55 \\
(90)\end{array}$ & - & - & $\begin{array}{l}4 \\
(7)\end{array}$ & $\begin{array}{l}2 \\
(3)\end{array}$ & - & - & $\begin{array}{r}61 \\
(100)\end{array}$ \\
\hline 社 & & 保 & $\begin{array}{l}152 \\
(88)\end{array}$ & ${ }^{4}{ }^{4}$ & - & $(1)^{1}$ & $\begin{array}{r}8 \\
(5)\end{array}$ & $\begin{array}{r}3 \\
(2)\end{array}$ & ${ }^{4}{ }^{4}$ & $\begin{array}{c}172 \\
(100)\end{array}$ \\
\hline 武 & & 赤 & $\begin{array}{l}115 \\
(64)\end{array}$ & - & - & (4) & - & $\begin{array}{r}51 \\
(29)\end{array}$ & $\begin{array}{l}6 \\
(3)\end{array}$ & $\begin{array}{r}179 \\
(100)\end{array}$ \\
\hline 五 & 路 & 加 & $\begin{array}{l}247 \\
(88)\end{array}$ & $\begin{array}{r}19 \\
(7)\end{array}$ & - & $\begin{array}{l}6 \\
(2)\end{array}$ & ${ }^{7}{ }^{7}$ & - & (1) & $\begin{array}{r}282 \\
(100)\end{array}$ \\
\hline 虎 & の & 閒* & $\begin{array}{c}336 \\
(80)\end{array}$ & - & $\begin{array}{r}64 \\
(15)\end{array}$ & (3) & - & - & $\begin{array}{l}15 \\
(2)\end{array}$ & $\begin{array}{r}427 \\
(100)\end{array}$ \\
\hline 関 & & 中 & $\begin{array}{l}183 \\
(92)\end{array}$ & - & - & $\begin{array}{c}12 \\
(6)\end{array}$ & (1) & - & $(1)^{2}$ & $\begin{array}{c}198 \\
(100)\end{array}$ \\
\hline
\end{tabular}

表一9 入院各科別の患者延数とその比率

\begin{tabular}{|c|c|c|c|c|c|c|c|c|c|c|c|c|c|}
\hline & & & 内 科 & 外 科 & 脸 外 科 & 整形外科 & 小児科 & 産婦人科 & $\begin{array}{l}\text { 皮竸. } \\
\text { 泌尿器科 }\end{array}$ & $\begin{array}{l}\text { 精 神 - } \\
\text { 神 経 科 }\end{array}$ & 眼 科 & その他 & 計 \\
\hline 豊 & & 島 & $\begin{array}{r}1,850 \\
(30)\end{array}$ & $\begin{array}{r}881 \\
(14)\end{array}$ & $\begin{array}{l}437 \\
(7)\end{array}$ & $\begin{array}{c}673 \\
(11)\end{array}$ & $\begin{array}{c}1,069 \\
(17)\end{array}$ & $\begin{array}{r}1,147 \\
(18)\end{array}$ & $\begin{array}{l}22 \\
(0)\end{array}$ & - & $\begin{array}{l}188 \\
(3)\end{array}$ & $(0)^{2}$ & $\begin{array}{l}6,269 \\
(100)\end{array}$ \\
\hline 社 & & 保 & $\begin{array}{c}3,592 \\
(42)\end{array}$ & $\begin{array}{r}1,696 \\
(20)\end{array}$ & $\begin{array}{l}353 \\
(4)\end{array}$ & $\begin{array}{l}723 \\
(9)\end{array}$ & $\begin{array}{l}120 \\
(1)\end{array}$ & $\begin{array}{r}891 \\
(11)\end{array}$ & $\begin{array}{l}386 \\
(5)\end{array}$ & - & $\begin{array}{l}248 \\
\text { (5) }\end{array}$ & $\begin{array}{l}465 \\
(4)\end{array}$ & $\begin{array}{l}8,474 \\
(100)\end{array}$ \\
\hline 武 & & 赤 & $\begin{array}{r}4,220 \\
(31)\end{array}$ & $\begin{array}{r}1,141 \\
(8)\end{array}$ & - & $\begin{array}{r}2,210 \\
(16)\end{array}$ & $\begin{array}{c}1,399 \\
(10)\end{array}$ & $\begin{array}{r}3,361 \\
(25)\end{array}$ & $\begin{array}{l}499 \\
(4)\end{array}$ & $\cdot$ & $\begin{array}{l}202 \\
(1)\end{array}$ & $\begin{array}{l}632 \\
(5)\end{array}$ & $\begin{array}{r}13,664 \\
(100)\end{array}$ \\
\hline 聖 & 路 & 加 & $\begin{array}{r}1,846 \\
(22)\end{array}$ & $\begin{array}{c}1,534 \\
(18)\end{array}$ & - & $\begin{array}{c}890 \\
(11)\end{array}$ & $\begin{array}{l}664 \\
(8)\end{array}$ & $\begin{array}{r}2,260 \\
(27)\end{array}$ & $\begin{array}{l}441 \\
(5)\end{array}$ & · & $\begin{array}{l}127 \\
(2)\end{array}$ & $\begin{array}{l}597 \\
(7)\end{array}$ & $\begin{array}{l}8,359 \\
(100)\end{array}$ \\
\hline 関 & & 中 & $\begin{array}{r}5,031 \\
(50)\end{array}$ & $\begin{array}{c}1,201 \\
(12)\end{array}$ & . & $\begin{array}{l}456 \\
(5)\end{array}$ & $\begin{array}{l}157 \\
(2)\end{array}$ & $\begin{array}{l}929 \\
(9)\end{array}$ & $\begin{array}{l}345 \\
(3)\end{array}$ & $\begin{array}{c}1,604 \\
(16)\end{array}$ & $\begin{array}{l}252 \\
(2)\end{array}$ & $\begin{array}{l}103 \\
\text { (1) }\end{array}$ & $\begin{array}{r}10,078 \\
(100)\end{array}$ \\
\hline
\end{tabular}


表一11 外来各科別の患者延数と艺の比率

\begin{tabular}{|c|c|c|c|c|c|c|c|c|c|c|c|c|c|}
\hline & & & 内 科 & 外 科 & 脸外科 & 整形外科 & 小児 科 & 座婦人科 & $\begin{array}{l}\text { 度 } \\
\text { 泌尿器科 } \\
\end{array}$ & 目喉鼻 & $\begin{array}{l}\text { 精 神 } \\
\text { 神 } \\
\end{array}$ & その他 & 計 \\
\hline 豊 & & 島 & $\begin{array}{r}2,847 \\
(21)\end{array}$ & $\begin{array}{r}888 \\
(6)\end{array}$ & $\begin{array}{l}467 \\
(3)\end{array}$ & $\begin{array}{c}1,554 \\
(11)\end{array}$ & $\begin{array}{c}1,450 \\
(11)\end{array}$ & $\begin{array}{r}2,500 \\
(18)\end{array}$ & $\begin{array}{r}1,061 \\
(8)\end{array}$ & $\begin{array}{l}878 \\
(6)\end{array}$ & - & $\begin{array}{r}2,182 \\
(16)\end{array}$ & $\begin{array}{r}13,727 \\
(100)\end{array}$ \\
\hline 社 & & 保 & $\begin{array}{r}2,835 \\
(20)\end{array}$ & $\begin{array}{r}1,120 \\
(8)\end{array}$ & $\begin{array}{l}795 \\
(5)\end{array}$ & $\begin{array}{r}1,755 \\
(12)\end{array}$ & $\begin{array}{l}875 \\
(6)\end{array}$ & $\begin{array}{c}1,668 \\
(12)\end{array}$ & $\begin{array}{r}2,141 \\
(15)\end{array}$ & $\begin{array}{c}1,280 \\
(15)\end{array}$ & - & $\begin{array}{r}1,996 \\
(8)\end{array}$ & $\begin{array}{r}14,465 \\
(100)\end{array}$ \\
\hline 武 & & 赤 & $\begin{array}{c}4,015 \\
(12)\end{array}$ & $\begin{array}{l}1,276 \\
\text { (4) }\end{array}$ & • & $\begin{array}{c}3,743 \\
(12)\end{array}$ & $\begin{array}{c}2,206 \\
(7)\end{array}$ & $\begin{array}{c}4,439 \\
(14)\end{array}$ & $\begin{array}{c}2,378 \\
(7)\end{array}$ & $\begin{array}{r}2,935 \\
(9)\end{array}$ & . & $\begin{array}{r}11,200 \\
(35)\end{array}$ & $\begin{array}{c}32,192 \\
(100)\end{array}$ \\
\hline 聖 & 路 & 加 & $\begin{array}{r}5,186 \\
(22)\end{array}$ & $\begin{array}{r}1,345 \\
(6)\end{array}$ & $\begin{array}{l}384 \\
(2)\end{array}$ & $\begin{array}{c}2,110 \\
(9)\end{array}$ & $\begin{array}{c}3,344 \\
(14)\end{array}$ & $\begin{array}{c}2,848 \\
(12)\end{array}$ & $\begin{array}{r}1,670 \\
(7)\end{array}$ & $\begin{array}{r}1,652 \\
(7)\end{array}$ & $\begin{array}{l}240 \\
(0)\end{array}$ & $\begin{array}{c}4,816 \\
(21)\end{array}$ & $\begin{array}{r}23,595 \\
(100)\end{array}$ \\
\hline 関 & & 中 & $\begin{array}{c}5,006 \\
(28)\end{array}$ & $\begin{array}{l}794 \\
(4)\end{array}$ & $\cdot$ & $\begin{array}{r}1,459 \\
\quad(8)\end{array}$ & $\begin{array}{c}1,720 \\
(10)\end{array}$ & $\begin{array}{c}2,069 \\
(11)\end{array}$ & $\begin{array}{r}1,498 \\
(8)\end{array}$ & $\begin{array}{r}1,393 \\
(8)\end{array}$ & $\begin{array}{l}852 \\
(5)\end{array}$ & $\begin{array}{r}3,336 \\
(18)\end{array}$ & $\begin{array}{r}18,127 \\
(100)\end{array}$ \\
\hline
\end{tabular}

因夕に診療各科別の外来患者数を 表一11 に示す。

\$. 脳 波

（1）入院-外来別件数：脳波の件数学入院と外来と にわけてみると表一12のようになる。脳波測定は手術 中におこなわれることもあるが，ここでは手術部におけ る使用を除いて集計した。割合からすると外来が 70〜 90\%と圧倒的に多い。ただく東二>だけはこの比率が まったく逆になっているが，件数の絶対值そのものが異 常に小さいので確かなことはいえない。

1956 年の報告では，少数調查例から入院対外来注ほぼ 半々の比率であるように推断したが，今やその様相がか わってきたことに注意したい。

表一12 大院・外来別脳波件数とその比率

\begin{tabular}{|c|c|c|c|c|c|c|}
\hline & 入 & 院 & 外 & 来 & \multirow{2}{*}{ 計 } \\
\hline & & $\mathbf{N}$ & I & $\mathrm{N}$ & $\mathrm{O}$ & \\
\hline 東 & - $^{*}$ & $\begin{array}{r}23 \\
(30)\end{array}$ & 0.2 & $\begin{array}{r}53 \\
(70)\end{array}$ & 0.2 & $\begin{array}{c}76^{\prime)} \\
(100)^{\prime}\end{array}$ \\
\hline 東 & 二* & $\begin{array}{r}17 \\
(85)\end{array}$ & 0.1 & (15) & 0.0 & $\begin{array}{r}20 \\
(100)\end{array}$ \\
\hline 豊 & 島 & $(10)^{5}$ & 0.1 & $\begin{array}{r}46 \\
(90)\end{array}$ & 0.3 & $\begin{array}{r}51 \\
(100)\end{array}$ \\
\hline 社 & 保 & ${ }^{8}{ }^{8}$ & 0.1 & $\begin{array}{r}66 \\
(89)\end{array}$ & 0.5 & $\begin{array}{r}74 \\
(100)\end{array}$ \\
\hline 武 & 赤 & $\begin{array}{r}5 \\
(9)\end{array}$ & 0.0 & $\begin{array}{r}48 \\
(91)\end{array}$ & 0.1 & $\begin{array}{r}53 \\
(100)\end{array}$ \\
\hline 聖 路 & 加 & $\begin{array}{r}27 \\
(17)\end{array}$ & 0.3 & $\begin{array}{l}132 \\
(83)\end{array}$ & 0.6 & $\begin{array}{c}159 \\
(100)\end{array}$ \\
\hline 虎 の & 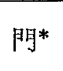 & $\begin{array}{r}32 \\
(26)\end{array}$ & 0.2 & $\begin{array}{r}89 \\
(74)\end{array}$ & 0.3 & $\begin{array}{r}121 \\
(100)\end{array}$ \\
\hline
\end{tabular}

1) 外来・入院別不明 1 を除く。

（2）入院各科别件数：すでに述べたよらに入院患者 の脳波検查件数はきわめて少ないから比率を云々するに は当らないが，参考のために診療科別の件数を挙げてお <（表-13）。

表一13 入院各科別脳波件数

\begin{tabular}{|c|c|c|c|c|c|c|c|c|}
\hline \multicolumn{3}{|c|}{. } & 内 科 & 外 科 & 脳外科 & 小児科 & 整形外科 & 計 \\
\hline 豐 & & 島 & 1 & - & 3 & 1 & - & 5 \\
\hline 社 & & 保 & 1 & - & 7 & - & - & 8 \\
\hline 武 & & 赤 & 1 & - & $\cdot$ & 3 & 1 & 5 \\
\hline 聖 & 路 & 加 & 3 & 6 & 3 & 15 & - & 27 \\
\hline
\end{tabular}

（3）外来各科刮件数：外来での脳波使用件数を診療 科別に分類したのが 表一14 である。全般的には脳外科
からの利用の大きい点に注目されるが，<武赤〉では小 児科汃活発に使っている。1956年調查の当時にくらべれ ば脳外科の進歩と普及がめざましいが，この傾向からす れば今後はますます脳波の件数む増えていくことになる のではなかららか。

表一14 外来各科別脳波件数ととの比率

\begin{tabular}{|c|c|c|c|c|c|c|c|}
\hline & 内 科 & 外 科 & 脳外科 & 整形外科 & 小児科 & その他 & 計 \\
\hline 東 一* & $\begin{array}{r}7 \\
(13)^{7}\end{array}$ & - & $\begin{array}{r}30 \\
(57)\end{array}$ & - & $\begin{array}{c}12 \\
(23)\end{array}$ & $\begin{array}{r}4 \\
(8)\end{array}$ & $\begin{array}{r}53 \\
(100)\end{array}$ \\
\hline 東 二* & (33) & - & $\begin{array}{r}2 \\
(67)^{2}\end{array}$ & - & - & - & $(100)^{3}$ \\
\hline 豊 島 & - & - & $\begin{array}{r}46 \\
(100)\end{array}$ & - & - & - & $\begin{array}{r}46 \\
(100)\end{array}$ \\
\hline 社 保 & - & (3) & $\begin{array}{r}64 \\
(97)\end{array}$ & - & - & - & $\begin{array}{r}66 \\
(100)\end{array}$ \\
\hline 武 赤 & (6) & $\begin{array}{r}11 \\
(23)\end{array}$ & - & $\begin{array}{r}1 \\
(2)\end{array}$ & $\begin{array}{r}31 \\
(65)\end{array}$ & ${ }^{2}$ & $\begin{array}{r}48 \\
(100)\end{array}$ \\
\hline 聖路加 & $\begin{array}{r}27 \\
(20)\end{array}$ & $\begin{array}{r}9 \\
(7)\end{array}$ & $\begin{array}{r}75 \\
(57)\end{array}$ & $\left.{ }^{3}\right)^{2}$ & $\begin{array}{r}18 \\
\text { (14) }\end{array}$ & - & $\begin{array}{c}132 \\
(100)\end{array}$ \\
\hline 虎の門* & $\begin{array}{r}18 \\
(20)\end{array}$ & - & $\begin{array}{r}53 \\
(60)\end{array}$ & $(2)^{2}$ & $\begin{array}{c}13 \\
(15)\end{array}$ & $\left.{ }^{3}\right)^{3}$ & $\begin{array}{r}89 \\
(100)\end{array}$ \\
\hline
\end{tabular}

\section{\$6. 筋電図}

すでに述べたように，筋電図の件数もその絶対值が小 さいから，内訳についてそれほぼ細かな分析の必要むな いと考えるが，一応，入院と外来とにわけてみると表一 15 のよらになる。どららかといえば，外来からの利用 の方が多い。なお，診療科別にみるとその大半が整形外 科によって占められている。

表一15 入院 $\cdot$ 外来別筇電図件数

\begin{tabular}{ll|rr|rr|r}
\hline & & 入 & 院 & 外 & 来 & 計 \\
\hline 東 & 一 & 乘 & 1 & 1 & 2 \\
東 & 二* & 4 & - & 4 \\
豊 & 島 & 1 & 4 & 5 \\
社 & 保 & 4 & 10 & 14 \\
聖 & 路 & 加 & - & 2 & 2 \\
虎 & の & 間 & 6 & 9 & 15 \\
\hline
\end{tabular}

\section{\$7. 基礎代謝}

（1）入院 - 外来別件数：基礎代謝の使われ方を入院 ・外来別にみたのが 表一16 である。件数の少ないく社 保>を除けば，大半 $(70 \sim 90 \%)$ が外来によって占めら れている。これも以前の調查では入院・外来を半々とみ てよいと結論したが，最近では傾向がかわってきている 
ことに注目する必要がある。

表一16 入院・外来別基礎代謝件数とその比率

\begin{tabular}{|c|c|c|c|c|c|}
\hline & & & 入 & 外 来 & 計 \\
\hline 東 & & - $^{*}$ & $(8)$ & $\begin{array}{r}35 \\
(92)\end{array}$ & $\begin{array}{r}38 \\
(100)\end{array}$ \\
\hline 東 & & $二^{*}$ & (9) & $\begin{array}{r}59 \\
(91)\end{array}$ & $\begin{array}{r}65 \\
(100)\end{array}$ \\
\hline 社 & & 保 & $\begin{array}{r}7 \\
(54)\end{array}$ & $\begin{array}{r}6 \\
(46)^{6}\end{array}$ & $\begin{array}{r}13 \\
(100)\end{array}$ \\
\hline 武 & & 赤 & $\begin{array}{c}6 \\
(23)^{6}\end{array}$ & $\begin{array}{r}20 \\
(77)\end{array}$ & $\begin{array}{r}26 \\
(100)\end{array}$ \\
\hline & 路 & 加 & ${ }_{(9)}^{2}$ & $\begin{array}{r}21 \\
(91)\end{array}$ & $\begin{array}{r}23 \\
(100)\end{array}$ \\
\hline & の & 閒* & $\begin{array}{r}11 \\
(28)\end{array}$ & $\begin{array}{r}28 \\
(72)\end{array}$ & $\begin{array}{r}39 \\
(100)\end{array}$ \\
\hline 関 & & 中 & (17) & $\begin{array}{r}25 \\
(83)\end{array}$ & $\begin{array}{r}30 \\
(100)\end{array}$ \\
\hline
\end{tabular}

（2）外来各科別件数：入院湴件数が少ないから，外 来のみについて診療各科別の集計をすると 表一17 のよ うになる。<東二>以外では, 内科がほとんでである。 <東二>では内科に次いで放射線科が相当の割合を占め ているが，これは甲状腺疾患の R I 治療などとの関連に よるものであろう。つまり他病院ではこの分が内科に包 含されていると考えてもよい。

表一17 外来各科別基礎代謝件数とその比率

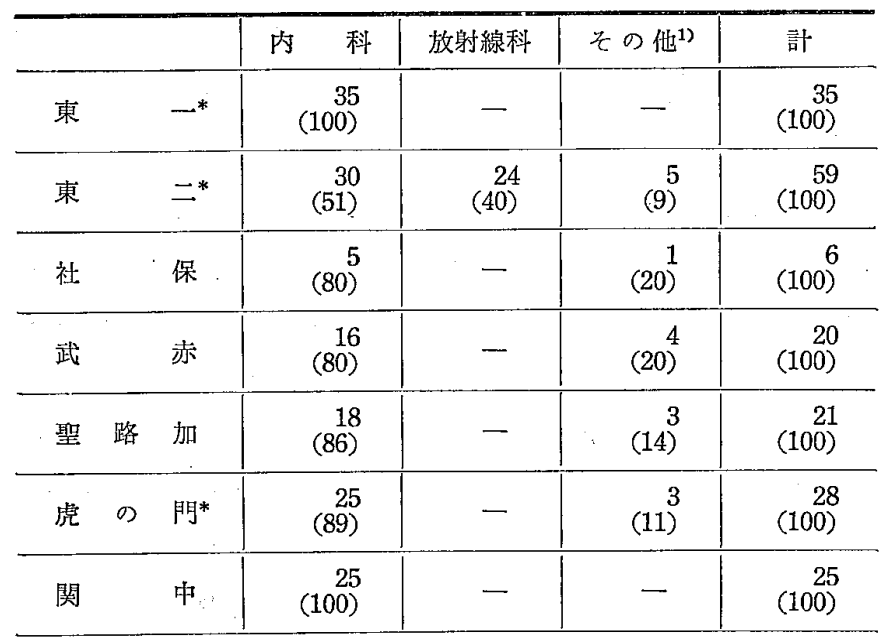

1）外科 $\cdot$ 産婦人科 $\cdot$ 小児科 $\cdot$ 耳鼻哂喉科

§8. 呼吸機能

呼吸機能検查も件数が少ないから余り問題にするには 及ばないようではあるが，敢えて同じような分析をして 表一18 入院・外来別呼吸機能件数と炎の此率

\begin{tabular}{|c|c|c|c|c|c|}
\hline & & & 入 & 外来 & 計 \\
\hline 東 & & -** & $\begin{array}{r}14 \\
(93)\end{array}$ & (7) & $\begin{array}{r}15 \\
(100) \\
\end{array}$ \\
\hline 東 & & 二* $^{*}$ & $(100)^{4}$ & - & ${ }^{4}{ }^{4}$ \\
\hline 広 & & 尾* & $\begin{array}{r}9 \\
(75)\end{array}$ & $\begin{array}{r}3 \\
(25)^{2}\end{array}$ & $\begin{array}{r}12 \\
(100)\end{array}$ \\
\hline 聖 & 路 & 加 & $\begin{array}{r}9 \\
(100)^{2}\end{array}$ & - & $\begin{array}{r}9 \\
(100)\end{array}$ \\
\hline 虎 & $\infty$ & 門* & $\begin{array}{r}42 \\
(53)\end{array}$ & $\begin{array}{r}38 \\
(47)\end{array}$ & $\begin{array}{r}80 \\
(100)\end{array}$ \\
\hline 関 & & 中 & $(100)^{1}$ & - & $(100)^{1}$ \\
\hline
\end{tabular}

みた（表一18）。上述の諸検查とは逆に，大部分が入院 による利用である。

\section{§9. 検查施設の規模算定}

（1）以上のデーターを基礎にして，実際の設計のた めのめやすをたててみたい。まず，病院の規模として次 の 3 つを想定する。

表一19 想 定 病 院 規 模

\begin{tabular}{|c|c|c|c|}
\hline & ベッド 数 & $\begin{array}{l}\text { 年聞 } 1 \text { 日平均 } \\
\text { 外来患者数 }\end{array}$ & 外来率 \\
\hline A & 200 & 500 & 2.5 \\
\hline B & 400 & 800 & 2.0 \\
\hline C & 600 & 1000 & 1.7 \\
\hline
\end{tabular}

いずれも慢性笑患患者を含まない一般病院とする。

（2）次に，入院-外来別 1 日当りの検查件数を，各 種目ごとの変動と比較的近い将来増とを勘案して次のよ うに仮定する。ただしこれは研究的な色彩をもたない一 般病院を前提としたものである。

表一20 1 日当り検查件数の推定值

\begin{tabular}{|c|c|c|c|c|}
\hline & & & 入院 100 ヘッッド当り & 外来患者 100 人当り \\
\hline 心 & 電 & 図 & 3.5 & 2.0 \\
\hline 脳 & & 波 & 0.3 & 0.5 \\
\hline 筋 & 電 & 図 & 0.05 & 0.07 \\
\hline 基 & 礎 代 & 謝 & 0.1 & 0.2 \\
\hline 呼 & 吸機 & 能 & 0.4 & 0.1 \\
\hline
\end{tabular}

（3）これらの仮定から 1 日当りの検查件数を算出寸 ると次のようになる。

表一21 病院の規模別に算定した 1 日当りの生理検査件数

\begin{tabular}{|c|c|c|c|c|c|}
\hline & & & A (200床) & B (400床) & C (600林) \\
\hline i & 電 & 図 & 17.0 & 30.0 & 41.0 \\
\hline 跚 & & 波 & 3.1 & 5.2 & 6.8 \\
\hline 筮 & 電 & 図 & 0.5 & 0.8 & 1.0 \\
\hline 基 & 礎 代 & 謝 & 1.2 & 2.0 & 2.6 \\
\hline 㖊 & 吸 譏 & 能 & 1.3 & 2.4 & 3.4 \\
\hline
\end{tabular}

（4）检查器械 1 台当りの別き能力は次のように考え られる。

(1)心電図：この検查法安静時心電図と賲荷心電図とに 分けられる。前者は最も一般的で 1 患者当りの測定所要 時間は約 10 分あればいい（乳児や肢体の不自由なもの を除く)。後者は患者に一定の運動をさせてから測定す るもので，順調にやっても 20２5 分くらいはかかる。

(ただし，負荷心電図検查を必要とするものは，心電図 総件数の $5 \%$ 程度を見込んで抢けばいい。)以上から心電 計 1 台当りの別き能力は， 1 時間に平均 4 人， 1 日の測 定実時間 5 時間（あとは資料や伝票の整理等に必要と考 える)として 1 日 20 人までであろう。

(2)脳波：これも普通の脳波と薬や光・音刺激を用いる 負荷脳波とに分けられる。1患者に対し最低 30 分ぐら いで終ることもあるが，個々の患者により異状脳波のあ らわれる時間に差があるから，普通 1 時間はかかるもの としなけ秃ばならない。すなわち 1 台の捌き能力は 1 日 
につき 5 人が限度であろう。

(3)筋電図：この検查は専門医が直接抗こなうもので， 1 検查につき準備などをも含めれば 1 時間前後を要す る。したがって 1 台当り，これも5人ぐらいであろう か。

(4)基礎代謝：これは朝食をとらない状態で測定しなけ ればならないため，検查は朝のらちに限られる。1患者 当り, 測定前約 30 分以上の安静を保ったのち, 垁際の 測定は 10 分程度でおわる。したがって器械台数よりは むしろ安静・測定のためのベッドの方が問題で，ベッド が確保されれば安静時の時間的口スを縮め，能率を上げ ることができる。実際の運用を通してみると器械 1 台に 対して 4 ベッドくらいの比率が適当とされる。

(5)呼吸機能：呼吸機能の測定は多種目の内容をもって いるが，例を一般脑機能検查にとれば，測定時間注約 30 分である。これに測定結果の計算その他の時間 30 分を 加えて患者 1 人当り 1 時間と考えればいい。な簡易呼 吸計を使用す扎ば 10 分たらず，スパイロメーターによ る測定ならば 20〜30 分である。いずれにせよ，1日5 〜6人とみて和けばよかろら。

（5）前項を 表一21 に当てはめれば，病院規模別の 所要器械台数あるいは 測定室数が得られる (表一22)。 ただし、ずれも 1 週 5〜6 日活動することを前提とす る。

表一22 病院規模別所要検査器械台数の試算結果

\begin{tabular}{|c|c|c|c|c|}
\hline & A-200床 & B-400床 & C-600床 & 注 \\
\hline 心 電図 & 1 & 2 & 3 & $\begin{array}{l}\text { 病室をの他で使用するた } \\
\text { 刑ータブル型を除く }\end{array}$ \\
\hline 脸波 & 1 & 2 & 2 & \\
\hline 筋 電 図 & 1 & 1 & 1 & \\
\hline 基礎代謝 & $1(1)$ & $1(2)$ & $1(3)$ & $\begin{array}{l}\text { （）邚は測定のためのべ } \\
\text { ッ数 }\end{array}$ \\
\hline 呼吸機能 & 1 & 1 & 1 & \\
\hline
\end{tabular}

\section{\$10. 要 約}

（1）生理機能検査は逐年漸増の傾向にある。月別に ほ，患者総数の変動にほぼ平行している。つまり，患者 のらち検査をらけるものの割合は病院ごとにほぼ一定し ていると考えてよい。

（2）種目別の件数についてみると，心電図が压倒的 に多い。次いで脳波の普及がやや目立ち，基礎代謝も少 々おこなわれている。筋電図・呼吸機能の件数はごく少 ない。

（3）これらの検查を大院と外来とにわけてみると， 心電図ではほぼ同率かむしろ外来の方がやや多い程度で あるが，脳波と基礎代謝では外来が大半を占める。呼吸 機能だけは逆に入院の方が多い。

（4）以上から，生理機能検查部門の配置は，どちら かといえば外来診療部からの利用㕝主に考えるべきこと が結論できる。主体をなす心電図についていえば，外来 各科のらち内科からの利用が大部分である。

（5）規模的な面に関しては，200 床前後までの病院 なら各種目とも 1 台で事足りるはずである。400 床程度 になれば心電図と铩波を2台に，さらに600 床ぐらいの 病院ならば心電図を 3 台に増やすといった程度をめやす にしていい。たた，400 床以上もの病院になると，診療 に研究的な色彩が濃くなってくる場合もあるから，相応 にゆとりを見込まねばならなくなるであろら。

この研究走進めるに当っては, 東京大学中央診療部の 樫田良精教授, 順天堂大学中央検查部の小酒井望教授を はじめ，数多くの先生方の御教示と御指導とをいたたい た。また調査集計に際しては当研究室の三好尚武・渡辺 晃伸・添田隆義の諸氏の協力を得た。な拉，調查を颃許 し衩がい種々便宜を計って下さった前記 9 病院の院長先 生はじめ検査部の諸先生方に対して厚く謝意を表する。 


\title{
TORSION OF BUILT-UP GIRDER
}

by Dr. TOSHIRO SUZUKI Assistant Prof. of Nagoya Institute of Tech., MAMORU KIMURA Structural Engineer of Takenaka Komuten Co., Ltd., Members of A.I.J.

The pourpose of this paper is to analyze the torsional problem of built-up girder with the stiffness matrix method.

The stiffness matrix method is finally equal to the displacement method which is satisfied the equilibrium conditions at the points of contact. But on the semi-closed section, we must consider the width of member.

Then, we assumed as followes

1) The cross section area of member is undeformed and remains plane

2) The torsional rigidity of each member is only St. Venant's torsion.

From these two assumptions, making the transformation matrixes of the stress, $T_{f}$, and the deformation, $T_{u}$, the main stiffness matrix reads

$$
K=T_{f} T^{T} k T T_{u}
$$

where $T$ is the co-ordinate transformation matrix and $k$ is the individual member stiffness matrix. Farthe. in order to check the appropriateness of this theory, we experiment. Generaly, in this kind of the torsional exp $i-$ ments of built-up girder, the influence of warping restraint is significant. Then on our experiments, we design $t$; experimental system without restraint.

The summary of this paper is as follows.

1) On analyzing the space frame, if we must consider the width of member, it is useful that we analyze with substituting the stiffened rod for the width of member.

2) The member of short length is influenced by the condition of ends, and the torsional rigidity decrease owing to the deformation of cross section on the end.

3) Increase of the torsional rigidity is due to the restrain of warping deformation for the most part.

U.D.C. $620.173: 624.074$

\section{TEST ON WELDED STEEL TRUSSES ADAPTED T-STRUCTURAL SHAPE FOR CHORD MEMBERS AND STEEL TUBE FOR WEB MEMBERS}

\author{
(Eccentric Panel Points : Part 3•1)
}

by Dr. KOICHIRO YAMADA, Prof. of Fukui Univ., Member of A.I.J.

This paper is the continuity of the previous paper written by the author in Transactions of Architectural Institute of Japan, No. 126, in August 1966. In this paper, in order to prevent the lateral buckling in testing a specimen constructed of the same two welded steel trusses, adapted the $T$-structural shape for their chord members, the steel tube for their web members and the eccentric panel points to make the construction of their panel points as simple as possible, was tested to find their strength and rigidity in the elastic and plastic behaviors. And the results of this test are discussed in comparison with the results of the elastic and plastic theoretical analysis, in which the second stresses for the welded steel trusses are considered and the plastic hinge theorem based on several assumptions is applied.

The results are as follows.

1) The yield load of the specimen in this test was nearly 23 tons and for larger loads than the yield one its rigidity was observed to decrease remarkably. And the above mentioned elastic and plastic behaviors of the specimen were found to nearly satisfy the results of this theoretical analysis.

Especially the elastic and plastic behaviors of the specimen in the process of its load becoming the yield one were sufficiently explained by this theoretical anailsis. And the yield load of the specimen, owing to the plastic hinges formed in its web members and the yielding of its lower chord member due to the tensil axial force and bending moment, was found to correspond to the limited load in which the specimen should lost most of the organization of the welded steel trusses and its upper chord member should begin to act as a beam.

However, the rigidity of the specimen for larger loads than the yield one was found to become larger than that of this theoretical analysis.

2) The dameges to the panel points of the specimen could not be observed until its breaking load due to the buckling of its compressive web member.

U.D.C. 725.51.011.1

\section{NUMBER OF PATIENTS RECEIVING PHYSIOLOGICAL TEST}

- Studies in the Functions and Design of Hospitals-

by Dr. MAKOTO ITO, Associate Prof. of Chiba Univ., Member of A.I.J.

The number of physiological test in hospital is increasing. The information as to the use of physiological test 
room is needed to determine its location and size.

This paper reports the number of in-and out-patients receiving each test, that is electrocardiograph, electroencephalograph, electromyograph, basal metabolism ratio, and respiratory function. Nine hospitals were chosen for investigation.

Some of the results of the studies are as follows:

1) It was found that the great majority of the test was held by E.C.G. and the most part of the rest was held by E.E.G. and B.M.R.

2) The proportion of the number of test between in- and out-patients in E.C.G. is nearly equal. Concerning the E.E.G. and B.M.R., the greater part of them is received by out-patients.

3) One room for each test is sufficient for the hospital having up to 200 beds. Two rooms will respectively be necessary for E.C.G. and E.E.G. rests of 400-bed hospitals. In case of 600-bed hospital, three E.C.G. test rooms will be needed.

U.D.C. $534.844 / .845$

\section{INVESTIGATIONS INTO THE PRECISION OF MEASUREMENT OF SOUND ABSORPTION COEFFICIENTS IN A REVERBERATION ROOM}

by Dr. MASARU KOYASU, Kobayasi Inst. of Phys. Res., Dr. SYO KIMURA, Nihon Univ., Dr. MINORU NAGATA, N.H.K. Tech. Res. Lab., Members of A.I.J.

Results of the 3 rd Round Robin Test in Japan have shown relatively large deviations in measured absorption coefficients.

To investigate the diffuse condition in a reverberation room, which was supposed to be one of the important factors for the precision of measurements, directional diffusitivity during decay process was introduced as the index of diffusitivity for the middle and high frequency regions. From the measurements of this index, the sound fields of all rooms shown in Fig. 17 could be regarded as the same order of diffusitivity, when the total area of suspended diffusing plates in each room would reach up to 80 percent of the floor area of the room.

The important factors for the disagreement of the absorption coefficients in the 3 rd Round Robin test would have to be found in other items.

To investigate the fluctuations of absorption coefficient related to the reverberation time measurements, experimental works were conducted in the following ways.

(1) Reference decay curves were sent to 13 institutes and were read by 25 persons.

(2) The absorption coefficient of identical test materials was measured by using the same instruments in 11 reverberation rooms. The reverberation time was read by only one person from the recorded decay curves.

(3) To check the effect of dynamic characteristics of a high speed level recorder, decay curves were recorded by each level recorder in respective institutes. These records were read at first by only one person and then by respective persons in each institutes.

From these results, it was concluded that the personal tendency for reading the decay curves and the dynamic characteristics of a high speed level recorder would play an important role for the precision of measurements of sound absorption coefficients in a reverberation room.

The 4 th Round Robin test, where the specifications for measurements were derived from this investigation, showed fairly good results.

U.D.C. $711.14: 711.582$

RISE OF LAND CAUSED ARROUND THE HOUSING ESTATE (The Case of the Hibari-ga-oka Housing Project constructed by Japan Housing Corporation)

by HISAYOSHI KONDOH, Kanto Branch Office, Japan Housing Corporation. member of A.I.J.

In this paper, the results of the four times investigation carried out every three years since 1955, on the land price of the plots arround the border of the projected area of the Hibari-ga-oka housing estate*, and the plots of Hoya area** will be reported.

When some land is purchased by Japan Housing Corporation (J.H.C.) for construction of a housing eastate, the land price arround projected area usually rises higher than the area without any project arround it (like Hoya).

The areas selected for study are shown in Fig. 1-5. Land prices of the plots for shop in front of the stations are usually corelated with the number of the passengers getting on and off at the station, as shown in Fig. 2-6. In our case, the land priceof the plot $(y)$ and number of the passengere $(x)$ are also corelated as shown in Fig. 2-7. The relation between the land price per unit square of the plot for the residence $(x)$ and the land price for the shop $(y)$ is shown in Fig. 3-2.

*) The Hibari-ga-oka housing estate was constructed by J.H.C. in 1959. It is located in Tanashi Town in Tokyo Metropolitan Area, about $20 \mathrm{~km}$. far from Tokyo Central Area. The housing estate has 2694 dwelling units. Area is about 31 ha.

**) Hoya is next station to the Hibari-ga-oka Station. 